\title{
Implementations of the Best Practices in Repayment, the Way to Improve Collections of the Due Students' Loans in Tanzania
}

\author{
Veronica R. Nyahende ${ }^{1}$ \\ ${ }^{1}$ Department of Planning, Research and ICT, Higher Education Students' Loans Board (HESLB), Dar es salaam, \\ Tanzania \\ Correspondence: Veronica R. Nyahende, Department of Planning, Research and ICT, Higher Education Students' \\ Loans Board, Dar es salaam, Tanzania. Tel: 255-763-406-080. E-mail: venicerobert1@gmail.com
}

Received: November 3, 2015

Accepted: December 14, $2015 \quad$ Online Published: December 28, 2015

doi:10.5539/hes.v6n1p60

URL: http://dx.doi.org/10.5539/hes.v6n1p60

\begin{abstract}
This study was designed to investigate the influence of the implementation of the best practices in repayment in the pre college preparation, in the in college period and in the after college period (the grace period and repayment) in increasing collections of the due students' loans. The study was geared towards achieving the following objectives: (1) To assess the influence of the implementations of the best practices in repayment in the Pre college preparations in improving collections of the due students loans; (2) To examine the influence of the implementations of the best practices in repayment in the in college period in improving collections of the due students loans; (3) To investigate the influence of the implementations of the best practices in repayment in the after college period (the grace period and repayment) in improving collections of the due students loans.

Data were collected from parents, prospective loans beneficiaries and students' loans beneficiaries in Dar es salaam city, in this study 5 secondary schools (Azania, Zanaki, Jangwani, Mbezi and Makongo), 5 universities (UDSM, DUCE, CBE, IFM and DIT) and 4 Organizations (HESLB, TPB, NBC and DUCE Academic staff) were visited. Data were collected from 267 respondents, 138 were from Kinondoni district, 65 from Ilala district, and 64 from Temeke. Data collected were analysed using the Statistical Package for Social Science (SPSS) data analysis tool.

The study concluded that, the implementations of the best practice in repayment in the pre college preparation, in the in college period and in the after college period (the grace period and repayment) has an influence in increasing collections of the due students' loans. In order to address these conclusions, the study recommends that HESLB should ensure the early education to the existing models and presentation to promote value of education, in the pre college preparations, presence of students financial aid offices, entry and exit counselling sessions, in the in college period as well as making sure that beneficiaries are reminded to repay, maintenance of the regular contacts with borrowers as well as establishment of contacts with dropouts in the after college period.
\end{abstract}

Keywords: best practices in repayments, pre college preparation, in college period, after college period, loan repayment, Higher Education Students' Loans Board (HESLB), Higher Learning Institutions (HLIs), collections

\section{Introduction}

Students' loans in this context encompass loans disbursed to students of Higher Learning Institutions (HLIs) for their tuition fees, research costs, meals, accommodations and any other educational related cost approved by respective institution (such as field practical training costs and special faculty requirements). Students' loans are becoming more important in this century due to ever increasing costs for higher education, due to the fact that most governments fail to fund costs for higher education through grants (Johnstone, 2009).

The ever increasing need for students' loans all-over the world have led into a need to establish a sustainable higher education students' loan schemes to manage the public allocated funds. Students' loan schemes exist in many countries, including developed countries such as Japan, Scandinavian countries and the U.S.A., wherein students borrowing phenomenon started between 1940s and 1950s, and Canada in 1960s (Woodhall, 2007).

The sustainability of these schemes will depend on how repayment has been handled to create revolving fund. In developing countries, Africa in particular, students' loan schemes started between 1965 and 1988, which led into increased rate of enrolments from 4 to 18 percent. Leading countries, were; Namibia, Ghana, Kenya, and Nigeria 
(Woodhall, 2007).

In Tanzania, financing for higher education existed in the form of cost sharing way-back before independence in year 1961 (Ishengoma, 2004). Therefore, students' loans financing is not a new phenomenon in Tanzania. In the late 1980's the cost sharing policy in Tanzania was reformed to correct previous implementation errors. Hence, cost sharing policy was planned to be implemented in three phases (Msolla, 2007).

(i) Phase I (1992/1993): Students and their parents/guardians were required to pay for travelling costs from home to universities (and the way back).

(ii) Phase II (1994/1995): In addition to the first phase item, students were required to pay for meals and accommodation costs, through loans, which were administered by the government. This loan was only disbursed to students studying in public higher learning institutions.

(iii) Phase III (2004/2005): In this phase parents/guardians were required to pay for tuition fees, special faculty requirement, field practical training, research, books and stationeries (on loan basis). It was during Phase III, when the students' loans scheme was established under the supervision of the Higher Education Students' Loans Board (HESLB).

This paper is organized in the following sections: section two presents the literature reviewed, research methodology will be presented under section three. Findings, discussion, conclusions and recommendations will be discussed under section four and five respectively. Finally section six will cover limitations and directions for future research.

Students' loans repayment is of vital important in the running and the sustainability of the students' loans schemes, apart from the applications of the appropriate repayment strategies implementation of the best practices in repayment is a factor to consider in enhancing collections of the due students' loans. This study was designed to investigate the influence of the implementation of the best practices in repayment in the pre college preparation, in college period and after college period (the grace period and repayment) in increasing collections of the due students' loans.

According to Nimal and Fernando (2008) best practices are procedures considered within an organization, or an industry. These are techniques that have shown superior results consistently.

\subsection{HESLB Establishment}

The Higher Education Students' Loans Board is a body corporate established under the Act Number 9 of 2004, as amended by Act no 9 of 2007 (CAP, 178) with the objective of assisting (on a loan basis) needy Tanzanian students who secure admission in accredited higher learning institutions, but who have no economic ability to pay for the costs of their education (HESLB, 2004). Functions of the Board are:

(i) To issue (and keep records) of loans and grants to eligible and needy students admitted in public and privately owned higher learning institutions located within the country and abroad.

(ii) To collect repayments for all loans issued to students since 1994 so as to re-lend the fund to other needy Tanzanian students.

(iii) To maintain collaborations and network with key stakeholders including higher learning institutions, employers and loan beneficiaries, and

(iv) To advise the government on matters relating to issuance and recovery of loans.

According to Nyahende (2013b) since HESLB started its operations in July 2005, students' enrollments and access of funds to the needy students have increased. On the other hand, number of universities/colleges has also increased from 30 to 78 (as distributed in Table 1). This growing demand poses challenges of loans disbursement and repayments to HESLB (Ishengoma, 2008). 
Table 1. Higher Education Institutions in Tanzania

\begin{tabular}{lllll}
\hline \multirow{2}{*}{ S/N } & \multirow{2}{*}{ REGION } & NUMBER OF HIGHER EDUCATION INSTITUTIONS \\
& & PRIVATE & PUBLIC & TOTAL \\
\hline 1 & Tabora & 2 & - & 2 \\
2 & Morogoro & 3 & 2 & 5 \\
3 & Ruvuma & 3 & - & 3 \\
4 & Mbeya & 4 & 3 & 7 \\
5 & Iringa & 3 & 1 & 4 \\
6 & Manyara & 1 & 1 & 2 \\
7 & Dodoma & 1 & 3 & 4 \\
8 & Arusha & 5 & 3 & 8 \\
9 & Kagera & 2 & - & 2 \\
10 & Tanga & 3 & - & 3 \\
11 & Mwanza & 2 & - & 2 \\
12 & Mtwara & 1 & - & 1 \\
13 & Kilimanjaro & 3 & 1 & 4 \\
14 & Dar es salaam & 9 & 18 & 27 \\
15 & Zanzibar-Unguja & 2 & 34 & 4 \\
\hline
\end{tabular}

Source: TCU (2015)

According to Table 1, the increased number of universities has lead to the increase in the demand for higher education due to the pooling effects imposed to the secondary level, number of enrolled students as well as number of graduates who are students' loans beneficiaries, therefore more challenges will be brought about in the repayment side, hence the need for the Board (HESLB) to be keen in the implementations of the best practices in repayment from the pre college preparations, the in college period and in the after college period (the grace period and repayment).

\subsection{Research Questions}

1) Does the implementations of the best practices in repayment in the Pre college preparations increases collections of the due students loans?

2) Does the implementations of the best practices in repayment in the In college period increases collections of the due students loans?

3) Does the implementations of the best practices in repayment in the After college period increases collections of the due students loans?

\subsection{General Objectives}

The general objectives of this study is to determine on whether the implementations of the best practice in repayments in the pre college preparation, the in college period and the after college period have an influence in the collections of the due students loans.

\subsection{Specific Objective}

1) To assess the influence of the implementations of the best practices in repayment in the Pre college preparations in increasing collections of the due students loans.

2) To examine the influence of the implementations of the best practices in repayment in the In college period in increasing collections of the due students loans.

3) To investigate the influence of the implementations of the best practices in repayment in the After college period (the grace period and repayment) in increasing collections of the due students loans. 


\section{Literature Review}

\subsection{Implementations of the Best Practice in Repayment}

\subsubsection{Best Practice in Pre College Period}

According to Nimal and Fernando (2008), during Pre-College preparation students intending to join colleges can be educated on how financing of higher education and repayment is being done, this can be possible through building an early intervention on models which already exists such a s GEAR UP (Gaining Early Awareness and Readiness for Undergraduate Programme). The students' loans scheme can use these programmes to bring changes in the repayments aspects. Students and their family can be reinforced on the value of the post-secondary education, this can be achieved using various case study presentations on how the family income is been determined by the level of education attained by an individual's, for example a professor is highly paid compared to the Masters individuals, also former students can be invited to show example of how education has changed their lives (Amrhein et al., 2000).

According to CSFI (2008), national campaign for educational opportunity and postsecondary study will also be helpful as a best practice in advocating the students' loans and repayments phenomenon. This can be achieved by working together with local, regional, and national media campaign to advocate on the available opportunities for college enrolments and how best to handle repayments of the given students' loans. The other best repayment practice is to get college information to students and parents as early as possible, Mori et al. (2006) suggested that, "we should hand out a packet of college information when the baby leaves the hospital", this means that new parents should get the college information on matters such as students loan $\mathrm{s}$ and repayment so that they can prepare for the college savings plan and how to handle repayments. Also information on students' loans and repayments can reach parents and students through collaboration with the local newspapers to provide focus articles on issues concerning college education, the sponsorship and repayments (CSFI, 2008).

Alberto et al. (2007) suggest that the other best practice is to target students and parents who are needy, meaning that they cannot afford the cost of their education. This can be achieved by working with schools within the community which will provide the lists and the contacts of students who require special educational assistance in terms of funding. This target group when catched will be educated on the importance of students' loans and how repayments can assist in creation of revolving funds to finance more and more needy students.

Provision of information to employees at their work place regarding preparation and planning for their children's future is the best practice because parents/guardian will get to know what to do in preparing their children for college enrollment, the students' loans and repayment aspects as well as employees can be educated through special arrangements in seminar sessions, during working hours or seminar can be conducted during staff meetings (Amrhein et al., 2000).

Rial et al. (2004) argue that support of career and college fair at the middle and high school will help in imparting knowledge on students' loans repayments, there should be a contact with bodies for University Accreditation like TCU (Tanzania Commission for Universities) in Tanzania which will provide detailed information on how to design effective college fair which will be useful for this purpose. This college fair should involve as many stakeholders as possible to get their direct input.

Most of the literatures indicate that implementation of the best practices in repayment in the pre college preparation increases collections of the due students' loans. Hence it is hypothesised that implementation of the best practice in repayment in the pre college preparation do increase collection of the due students' loans.

$H_{1} \quad$ Implementations of the best practices in repayment in the pre college preparation increases collections of the due students'loans.

\subsubsection{Best Practice in College Period}

According to Misino (2004) students spend most time in college ranging from three to five or more years, at this time students do enjoy the students' loans which are given to support their studies as well as their living within the college. Students need to be attached mostly to the students' financial aids offices for receiving and updating of all necessary information concerning their loans. Financial aids offices can proactively prevent defaults.

As a best practice in the college, conducting of the entrance and exit counselling sessions is the most important event to remind students of their obligations to repay the loans given Alberto et al. (2007). Also Brachfield (2002) argued that the counselling session can be made more effective by having a standardized presentation year after year, also the exit and entrance counselling has to be interesting and careful prepared. Include parents in the counselling sessions especially if the borrowers are dependent students, parents are in a better position to help 
their children to borrow wisely. Use of the online exit and entrance counselling on a website created for students, the website must be available for 24 hours a day, 7 days a week. Students' borrowers have to be reminded of their obligations to repay the students' loans after graduation (Rial et al., 2004).

Devaney and Patricia (2006) suggest that using all types of communications is another best practice in college, he continued to argue that one to one contact works for some people but others prefer impersonal contacts like use of websites. Most of the people respond best when they know they have an individual treatment which is a sign that they are cared. In improving communication with students one has to use personalized communication on face to face meetings, direct students to go to good websites which have been developed by the school, and the use of emails to communicate with students throughout their enrollment. Regular communication increases the bond of the students to school hence assurance of the likelihood that they will complete their program (Alberto et al., 2007).

Regular contact with students' borrowers can be achieved through the use of email which has low cost with high impact, information sent to students need to be relevant, simple, and interesting. Also experienced lenders can give a shared experience on how to communicate with students' during the In College Period. Therefore communication with students' borrowers is important to ensure collections of the due loans, as it helps in reminding students' borrowers of the loans they have and their obligations to repay when they leave the school (Misino, 2004).

Herr and Burt (2005) explain that, identification and focusing on the high risk borrowers is among the best practice to ensure collections of the due loans. Targeting the risk borrowers through intensive counselling can create repayment attitudes and avoid defaulting. After identification of the risk groups of borrowers you can concentrate your efforts first to those students. For example provision of exit interviews to drop outs is vital because drop out borrowers have a high risk of defaulting. In this case counsellors have to prepare discussion regarding future plans and review of the repayment obligations and options.

As a best practice during the In College Period borrowers have to be reminded repetitively that loans are not grants and must be repaid. To ensure that students understand that they are borrowing money and there must be the use of simple and clear languages in the entrance sessions during counselling, borrowers have to read careful the materials they are signing. Loan counselling sessions have to be prepared and attendance has to be insisted, also loan statements must be issued to borrowers annually showing the amount borrowed, the monthly payments, the interest and the principal owed (Alberto et al., 2007).

Brachfield (2004) explained that promotion of earlier payments during enrollment is also a best practice, most students' loans schemes do not provide an optional of making payments while student borrowers are in college or are in grace period, this can bring misconception to some students, they can think that none of their financial aids needs to be repaid. Therefore, by persuading students to repay even a small amount while they are in college will begin to develop repayment habits, this can be achieved through education to students on the effects of interest that accumulates over a long period, also by having presentations as a case study from students who are actually making early payments.

According to Nyahende (2013a), students' borrowers has to be encouraged to study hard so as to avoid drop out, as students who leave the college especially in the first year of enrollment are most likely to default, college completion is a critical predictor of loan repayments. Misino (2004) argues that hiring of default specialists is another best practice during In College Period, default specialist will help in reducing default rate as he/she will have an excellent communication and listening skill to persuade students to repay their loans on time. The default specialist will have knowledge of the loans scheme available, the requirements and the lending practice so he/she can easily educate students' borrowers especially on the consequences of not paying back the loans. The default manager will establish regular contacts with the lender (students loans scheme in the case of Tanzania on all matters concerning repayments, loan disbursements etc, also she/he will document all the problems concerning lending and communicate them in finding long term solutions (Devaney \& Patricia, 2006).

According to the literature reviewed it has been hypothesized that implementations of the best practice in repayment in the in college period increases collections of the due students' loans.

$\mathrm{H}_{2}$ Implementations of the best practices in repayment in the in college period increases collections of the due students'loans.

\subsubsection{Best Practice in After College Period (Repayment and the Grace Period)}

According to HESLB (2014b), after completion of their studies, students' borrowers are given grace period before starting repaying their loans, In Tanzania students' borrowers are given a maximum of one year as a grace 
period. Best practices during this period includes, frequent contacts with borrowers which will be helpful in preventing defaults, borrowers are likely to relocate when they leave the college therefore regular contacts need to be maintained to know their whereabouts.

Alberto et al. (2007) argued that reminder should be send to graduates on when to start repaying their loans and at what rate. Borrowers will be contacted immediately after they enter grace period and several times during the period, do not wait until one month before the repayment start date. Educate the borrowers on loans consolidation and other repayment options. Remind them of the repayment start date 2 months before ending of the grace period. Brachfield (2004) suggested that students' borrowers should be encouraged to repay their loans during grace period, this will help them to consider loan repayments in their budget as they graduate and during job hunting. Using all available debt management alternatives, here you can set the payment due date to fit in the borrowers' pay date, inform the borrowers on the grace period materials, in Tanzania all collections are made upon salaries/income at $8 \%$ of the borrowers' salaries and are determined on the payday (HESLB, 2015b).

It was explained by Rial et al. (2004) that, the use of skip tracing is another best practice, the borrowers can be traced and located after having enough information, when borrowers are traced on their location then is a good chance of enhancing repayment and avoiding defaults. Locating of students borrowers can be through the use of other partners such as Tax departments and employees database to trace borrowers. Enhancement of coordination among loan process partners like guarantors, employers, social services institution example health insurance need to be updated of the borrowers' information frequently, the students' loans scheme need more coordination with these partners (Misino, 2004).

As advocated by Alberto et al. (2007), drop out are more likely to default than students who complete their programmes, therefore knowing immediately when student drop out will help in establishing contacts with them, hence reduction in the chances of defaulting. This can be achieved through establishment of record keeping and the alert system to tell when there is students borrowers who leave the college. Regular communication with the students' borrowers will give signals of the drop outs, also class instructors can help as informer to the registrar's office when a students in their classes stop showing up (Brachfield, 2002).

According to Amrhein et al. (2000), re involvement of the drop out back to school will be a solution to reduce default, this can be achieved by finding out the reasons for their drop outs and how they can be taken back to college, involvement of lectures is important here. Tracking of the transferred students among the colleges is one of the best practice, students should be tracked through the central admission board which will indicate the whereabouts of the student, in Tanzania it is easy to track transfers as the first payment must be signed by the recipient at the respective university and must be certified by the responsible official (HESLB, 2014c).

Therefore it is hypothesized that implementations of the best practices in repayment in the after college period increases collections of the due students' loans.

$\mathrm{H}_{3}$ Implementations of the best practices in repayment in the after college period increases collections of the due students'loans.

\subsection{Conceptual Framework}

The main concern of this paper is to the influence of the best practices in repayments in repayments in the pre college preparation, the in college period and the after college period in increasing collections of the due students' loans in Tanzania. As explained in the Literature reviewed the conceptual framework which shows the relationship between the implementations of the best practices in repayment in the pre college preparation, the in college and the after college period with the increased in the collections of the due students' loans has been developed as shown in Figure 1. 


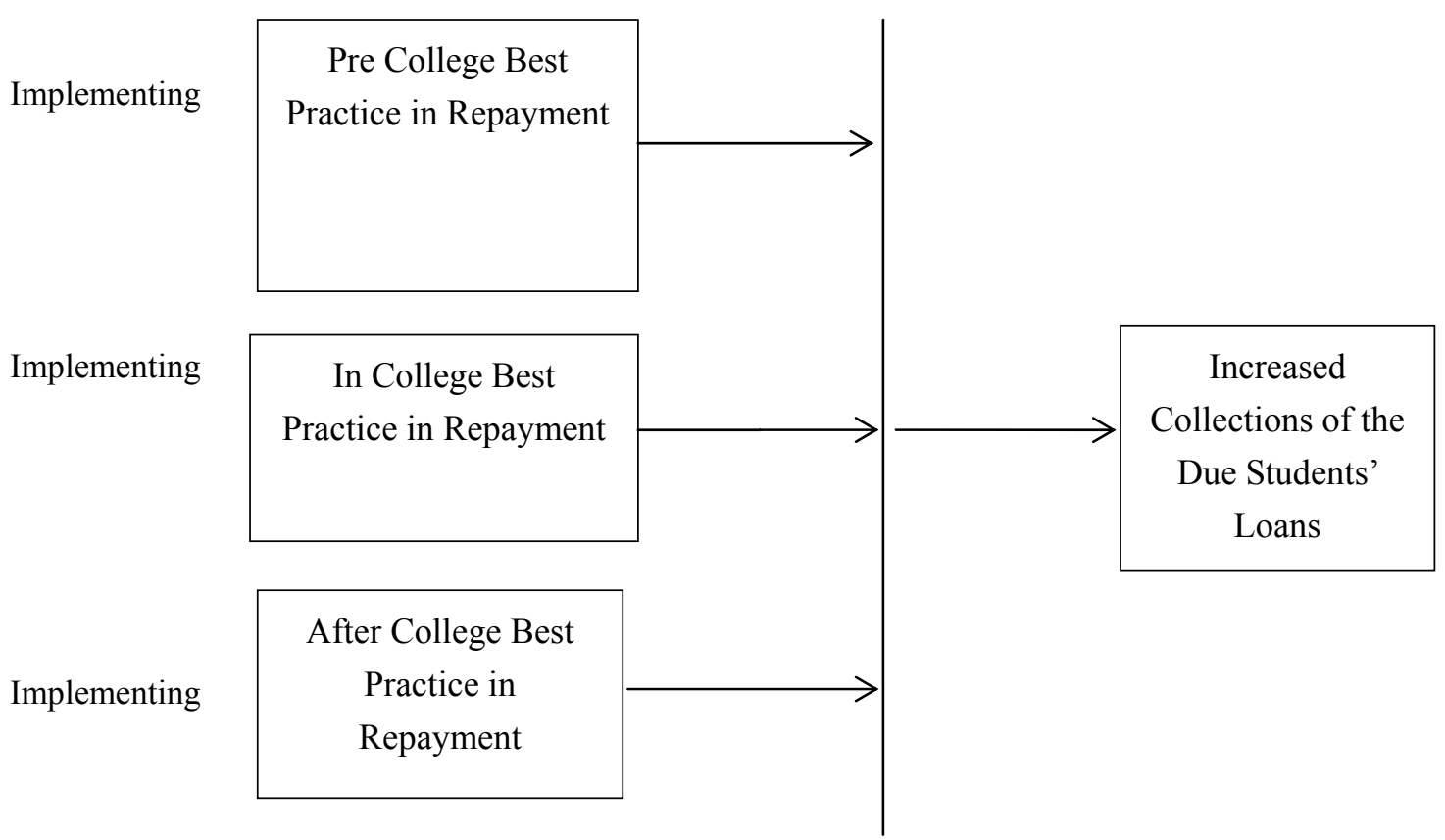

Figure 1. Concludes that the increased collections of the due students' loans in Tanzania is dependent upon the implementations of the best practices in repayments in all stages of students life that is in the Pre College preparations, the In College period and the After College period

\subsubsection{Pre College Preparation}

During the pre college preparation the researcher was expected to see the implementations of all the best practices in repayments supposed to be practiced in this stage of school life. Pre College preparation stage is of vital important and has an influence at the later stage of repayments; this is because students and parents need to be educated at the early stage about the students' loans and the important of repaying back to arose their interest. For instance the researcher was expected to see implementations of various best practices such as early education to the existing models (groups), presentations to promote value of education, national campaign to promote education from secondary level both nationally and locally, organization of college fair to educate on loan repayment and employees' education at their work place.

\subsubsection{In College Period}

Students' loan beneficiaries do enjoy the loans given during the In College period. At this stage the researcher was expected to see all the necessary best practices in repayment being implemented. The in college period is of vital important as it involves the actual implementation of the loans provisions to students. At this stage the researcher was expected to see implementations of various best practices such as presence of students financial aid offices, entry and exit counselling sessions, loan provision contracts are being read carefully, presence of exit interview to drop out and employment of default specialist.

\subsubsection{After College Period (Repayment and the Grace Period)}

During after college period the researcher was expected to see and prove the implementation of the best practice in repayment in order to enhance collections of the due students' loans. The after college period which include the repayment and grace period is of vital important in the collection cycle because students' loans beneficiaries are now graduated from various colleges/universities and they start moving out of the college/universities searching for employments/doing business to start their life after college. During this stage best practice needs to be implemented carefully to ensure their traceability so as to enhance collection of the due students' loans. Various practices which were expected to be seen by the researcher includes beneficiaries reminded to repay 2 months before end of the grace period, maintenance of the regular contacts with borrowers, beneficiaries reminded on the repayment start date and rate, establishment of contacts with dropouts and setting of the repayment date on the pay day. 
Conceptual framework explaining all the items under each independent variable is as shown in Figure 2.

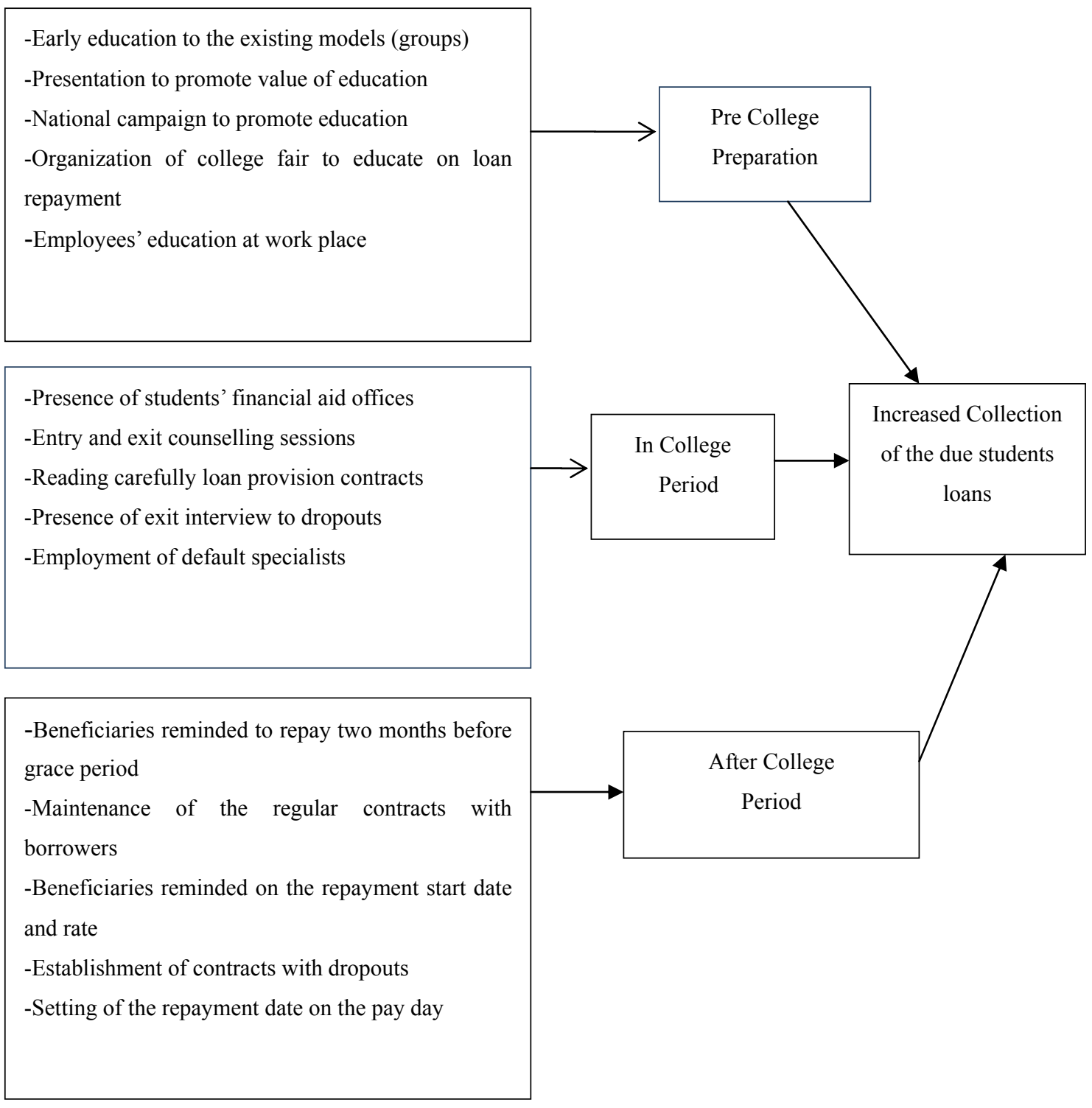

Figure 2. Conceptual framework

\subsubsection{Increased Collections of the Due Students' Loans}

Increased collections of the due students' loans is an independent variable, in this paper collections of the due students loans is expected to be influenced by the proper implementations of the best practices in repayment in the pre college preparation, in college period and after college period.

\subsection{Students' Loans Issuance at HESLB}

A core function of HESLB is loans allocation, disbursement and overseeing loan repayment to eligible students (who are Tanzanians by nationality) and enrolled in accredited higher learning institutions located within or outside the country (under bilateral arrangements) to undertake specialised diplomas and undergraduate degree courses. Loans are disbursed to Masters and PhD students studying within the country, if and only if, they are members of the academic staff in higher learning institutions. Allocation and Disbursement activities are done by the Directorate of Loans Allocation and Disbursement (HESLB, 2015c). 
Initially, Students' loans were interest free. However, as from year 2011/2012 all disbursed loans were subjected to an interest charge of 6\% per annum (HESLB, 2015d). Furthermore, in 2014/2015 the Government accepted the request by HESLB to charge interest rate at $6 \%$ to all students' loans retrospectively starting way back from $1994 / 1995$ to date.

Loans awards differ from one student to another based on social economic status, whereby neediness of the applicant is determined through Means Testing as per the formula indicated below.

Need for the Loan $=$ COA-RES* (Adjustments)

Where:

(i) Adjustments $=(\mathrm{O}+\mathrm{D}+\mathrm{SP})$

(ii) $\mathrm{COA}=$ Cost of Attending higher learning institutions

(iii) $\mathrm{RES}=$ Resource/Ability to pay

(iv) $\mathrm{O}=$ Orphanage

(v) $\mathrm{D}=$ Disability

(vi) $\mathrm{SP}=$ Single Parent

With the absence of Smart Card based National IDs, the HESLB has been forced to use proxies in Means Testing, beginning 2011/2012. Loanable items includes: (i) Tuition, (ii) Special faculty requirement, (iii) meals and accommodation, (iv) books and stationeries, (v) research expenses, and (vi) field and practical training. Loanable items which are testable under means testing as explained in the formula above are Tuition and Special Faculty requirement (HESLB, 2015d).

Since year 2012/2013 to 2014/2015 HESLB has disbursed loans to 92,064 students against 167,306 received applications, as detailed in Table 2.

Table 2. Number of applications and allocations

\begin{tabular}{lllllll}
\hline Year & $\begin{array}{l}\text { No. } \\
\text { Applications }\end{array}$ & $\begin{array}{l}\text { of } \\
\text { Allocations }\end{array}$ & $\begin{array}{l}\text { of } \\
\text { Allocated }\end{array}$ & $\begin{array}{l}\text { students } \\
\text { (\%) }\end{array}$ & $\begin{array}{l}\text { Total } \\
\text { Disbursed }\end{array}$ & Amount \\
\hline $2012 / 2013$ & 49,914 & 29,097 & $58 \%$ & $100,622,564,061$ \\
$2013 / 2014$ & 55,033 & 33,494 & $61 \%$ & $118,913,339,548$ \\
$2014 / 2015$ & 62,359 & 29,473 & $47 \%$ & $104,380,919,228$ \\
Total & 167,306 & 92,064 & $55 \%$ & $323,916,822,837$ \\
\hline
\end{tabular}

Source: HESLB (2015a): Exchange rate 1USD = TZS 2,149.45 (XE Currency API, 2015)

Figure 3 shows the gap between number of applications and allocated students for the period between 2012/2013, $2013 / 2014$, and $2014 / 2015$. The gap of 75,242 un allocated students is due to insufficient fund available to finance students. The Government is experiencing deficit in its budget due to the increased competing demand by various priority sectors such as security and water, also repayment which is another source of financing has got a lot of challenges due to poor implementation of the best practises in repayment at all stages of the higher education students' life in Tanzania. Therefore there is a need for proper and accurate implementations of the best practices in repayment from the pre college preparation, in college period and the after college period (grace period and repayments) so as to increase collections of due students' loans. 


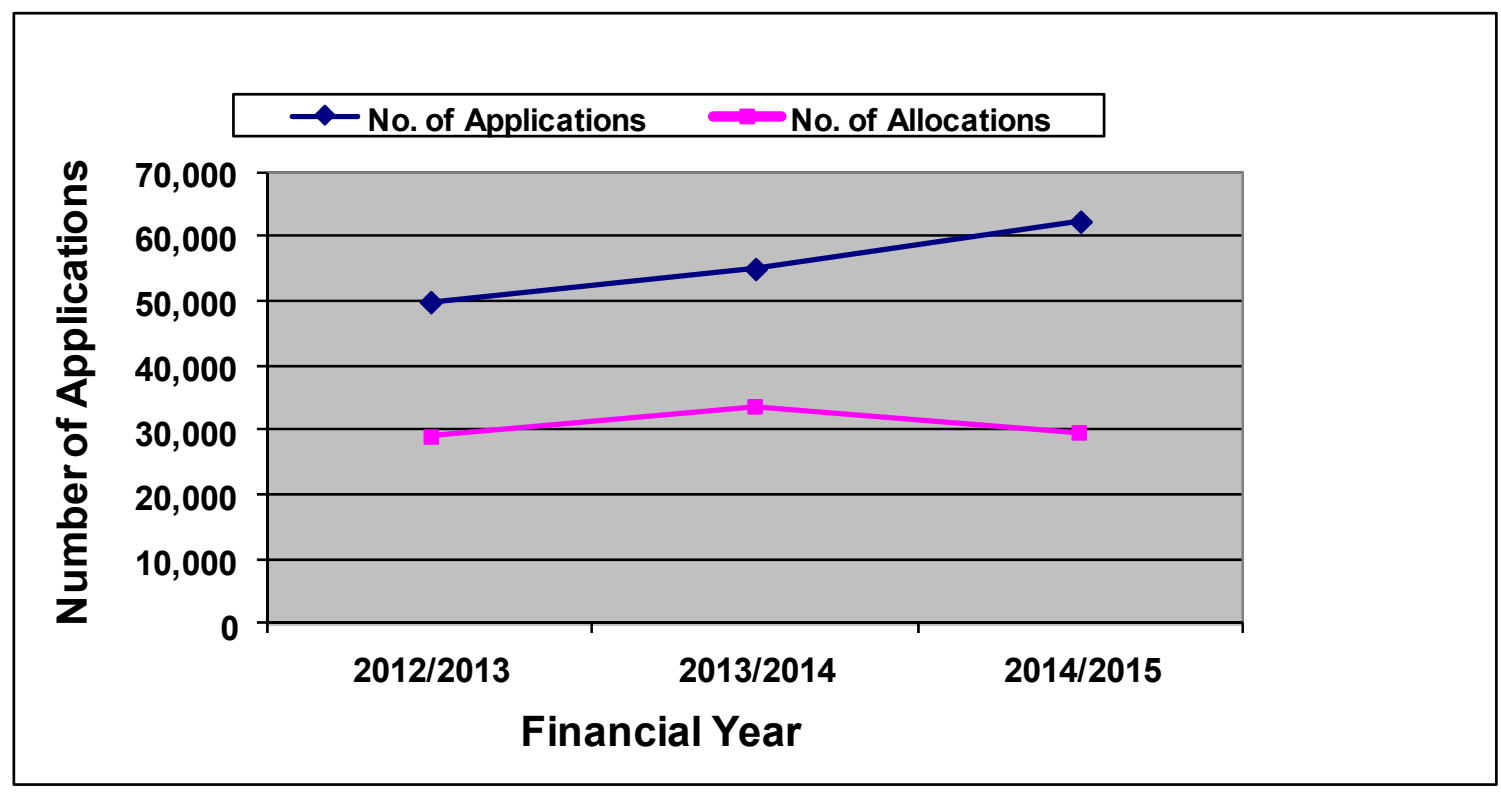

Figure 3. Loan applications VS allocations between 2012 and 2015

Figure 4 explains the increased amount of fund disbursed for the three consecutive years 2012/2013, 2013/2014 and $2014 / 2015$.

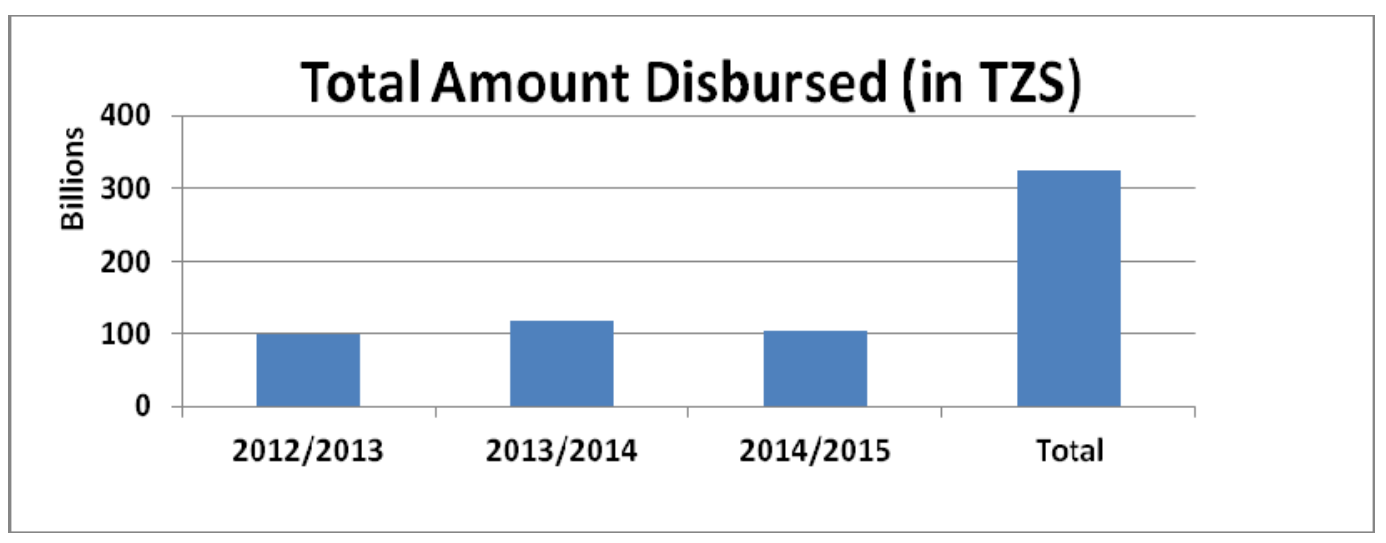

Figure 4. Total amounts disbursed between 2012 and 2015

The growing enrollment at lower levels which feed into higher education has been raising the demand for higher education and its financing. Therefore government subsidy does not cope with the increasing demand for funding. Not only that, but also poor repayment trend as a result of poor implementation of the best practices in repayment also abridge the growing gap.

Apart from the inability of the Government through HESLB to satisfy demand for Loanable fund, demand for students' loans has been increasing year after year as indicated by the increase in the number of students who were given loans as shown under Table 3 . 
Table 3. Number of students given loans and amount loaned from 1994/1995 to 2014/2015

\begin{tabular}{|c|c|c|}
\hline Financial Year & $\begin{array}{l}\text { Number } \\
\text { Students }\end{array}$ & Amount Loaned (TZS Billion) \\
\hline \multicolumn{3}{|l|}{ By the Government } \\
\hline $1994 / 1995$ to $2004 / 2005$ & 48,378 & \\
\hline Sub total & 48,378 & $51,103,685,914$ \\
\hline \multicolumn{3}{|l|}{ By HESLB } \\
\hline $2005 / 2006$ & 42,729 & $56,111,371,483$ \\
\hline $2006 / 2007$ & 47,554 & $76,193,757,565$ \\
\hline $2007 / 2008$ & 55,687 & $110,751,964,205$ \\
\hline $2008 / 2009$ & 58,798 & $139,093,681,094$ \\
\hline $2009 / 2010$ & 72,035 & $186,484,721,684$ \\
\hline $2010 / 2011$ & 92,791 & $224,936,870,422$ \\
\hline $2011 / 2012$ & 94,773 & $318,397,826,858$ \\
\hline $2012 / 2013$ & 96,818 & $315,836,086,462$ \\
\hline $2013 / 2014$ & 96,325 & $328,313,445,534$ \\
\hline $2014 / 2015$ & 100,839 & $335,213,197,743.82$ \\
\hline Sub total & 758,349 & $2,091,332,923,050.82$ \\
\hline GRAND TOTAL & 806,727 & $2,142,436,608,964.82$ \\
\hline
\end{tabular}

Source: HESLB (2014a): Exchange rate IUSD = TZS 2,149.45 (XE Currency API, 2015)

Table 3 Shows that there has been an increase in the number of students' loans beneficiaries and the amount loaned since HESLB establishment in year 2005/2006. A sharp increase between 1994/1995-2004/2005 and 2005/2006-2014/2015 is due to the fact that currently, loans are disbursed to students in all accredited public and privately owned HLIs, whereas prior to the establishment of HESLB only students in public accredited HLIs were being allocated loans (HESLB, 2008).

Despite the presence of students' loans to support higher education in Tanzania, participation, admission and general enrollment ratio in higher education in Tanzania is still low because of limited funding compared to neighbouring and other SADC countries (Ishengoma, 2008). Table 4 shows data on gross enrolment ratios in higher education in Tanzania and some selected African countries.

Table 4. Gross enrollment ratios in higher education for selected Sub Saharan African countries

\begin{tabular}{ll}
\hline Country & Gross Enrollment Ratio \\
\hline Tanzania & 1.0 \\
Kenya & 3.0 \\
Uganda & 3.0 \\
Burundi & 2.0 \\
Rwanda & 3.0 \\
Mozambique & 1.0 \\
Botswana & 6.0 \\
Angola & 1.0 \\
Lesotho & 3.0 \\
Zambia & 2.0 \\
Swaziland & 5.0 \\
\hline
\end{tabular}




\begin{tabular}{ll}
\hline Namibia & 6.0 \\
South Africa & 15.0 \\
Zimbabwe & 4.0 \\
\hline
\end{tabular}

Source: GUNI (2007)

The low admission and enrollment rate in Tanzania shown in Table 4 is a result of the limited funding caused by poor loan repayment experienced by the HESLB as well as the limited funding from the Government due to deficit in its budget, this situation call for the need for a proper implementations of the best practices in repayments to increase collections of the due students' loans.

\subsection{Research Hypotheses}

According to the literature reviewed and the conceptual framework developed, three hypotheses were derived from the three specific objectives. Evidence will be obtained from each hypotheses on how the increased collections of the due students' loans has been influenced by the implementations of the best practices in the pre college preparations, the in college period and the after college period.

Therefore the following hypotheses were developed and tested:

$H_{l}$ Implementations of the best practices in repayment in the pre college preparation increases collections of the due students' loans.

$\mathrm{H}_{2}$ Implementations of the best practices in repayment in the in college period increases collections of the due students' loans.

$\mathrm{H}_{3}$ Implementations of the best practices in repayment in the after college period increases collections of the due students' loans.

\section{Methodology}

\subsection{Research Design}

Research design is an outline of how an investigation will take place (Saunders, Lewis, \& Thornhill, 2007). A research design includes how data is to be collected, what instruments will be employed as well as intended methods of data analysis. In this cross sectional research design the research was guides by hypotheses and the 5 -likert-scale type of questions.

\subsection{The Population, Sample Size and Sampling Procedures}

\subsubsection{Population and Sample Size}

Parents, prospective students' loans beneficiaries and students' loans beneficiaries from Azania secondary school, Zanaki secondary school, Jangwani secondary school, Mbezi beach secondary school, Makongo Secondary school, University of Dar es salaam (UDSM), Dar es salaam College of Education (DUCE), College of Business Education (CBE), Institute of Finance Management (IFM), Dar es salaam Institute of Technology (DIT), Higher Education Students' Loans Board (HESLB), Tanzania Postal Bank (TPB), National Bank of Commerce (NBC), and DUCE Academic staff formed the population of this study. Most of the secondary schools, universities and organizations chosen are government affiliated either at $100 \%$ or in some percentages ownership, this is because these were the targeted beneficiaries of the students' loans. However currently in Tanzania some other private schools, colleges and organisations benefited from the students' loans as well. Universities chosen are the big universities which accommodates many students compared to other universities outside the Dar es salaam city, also most graduated loans beneficiaries are attracted to work in the government sectors within the city so the researcher found it convenient to collect data in the Dar es salaam city.

Sample was calculated using the sampling formulae in which a total of 267 respondents were considered from parents, secondary schools, universities and from the chosen organizations. The researcher considered the sample after studying the list of the employed students' loan beneficiaries from the Association of Tanzania Employers (ATE), the list of the current students loans beneficiaries from the Higher Education Students' loans Board (HESLB) database and the list of potential students' loans beneficiaries (primary and secondary school level students) from Basic Education Statistics in Tanzania (BEST) obtained at the Ministry of Education, and Vocational Training (MoEVT). The researcher decided to use a sample of 267 respondents after being satisfied of the availability of the respondents. 


\subsubsection{Sampling Procedures}

5 Colleges/Universities, 5 Secondary schools and 4 organizations were randomly chosen to form a group of 3 clusters namely the pre college preparations, the in college period and the after college period, in which prospective students' loans beneficiaries and loan beneficiaries were chosen from each cluster obtained. Given the researcher's knowledge that the selected sample could give the data needed the researcher used the purposive sampling techniques instead of other sampling techniques. In this study the researcher needed the respondents who are prospective students' loans beneficiaries and the current students' loans beneficiaries who can have the knowledge on whether there is implementation of the best practices in repayment in the pre college preparations, in college period and after college period which increases collections of the due students' loans.

\subsection{Data Collection}

Primary and secondary data were obtained quantitatively in this study:

\subsubsection{Primary Data}

Using the primary data the researcher obtained information on whether the best practices in repayments has been implemented in the pre college preparations, the in college period and in the after college period. An examples of these information includes evidence of the early education concerning students' loans and repayments to the existing models (groups), presentations to promote value of education, national campaign to promote education from secondary level both nationally and locally, organization of college fair to educate on loan repayment and employees education at their work place, presence of students financial aid offices, entry and exit counselling sessions during the in college period as well as maintenance of the regular contacts with borrowers during the after college period.

\subsubsection{Secondary Data}

Using the secondary data the researcher obtained information from HESLB documentation in matters regarding various strategies employed in improving collections of the due students' loans, the challenges associated with collections of due students' loans as well. HESLB strategic plan was also reviewed to know the future plans regarding repayments of the due students' loans. Perusal in the Loan Management System (LMS) and the sample of the application forms to understand the trend of applications, the students' ability to pay and the allocated universities/colleges.

The researcher also obtained secondary data from Association of Tanzania Employers (ATE) in which information regarding employees qualifications in order to understand on whether an employee is a loan beneficiary or not. Basic Education Statistics data from MoEVT were also revised to understand number of students in various universities and secondary schools, secondary school (A level) graduation status as well as the enrollement of the same was also studied.

\subsection{Data Analysis}

Software Package for Statistical Science (SPSS) were used to analyse the data collected in this study and the analysis technique were the correlation and regression. Therefore the general multiple linear regression model will be presented by the following formula:

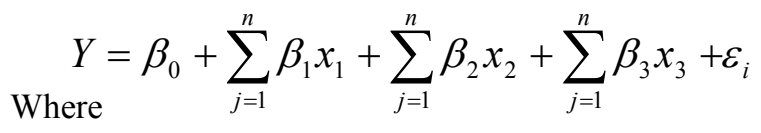

$Y \quad$ Represents a dependent variable which is the increased collections of the due students' loans in Tanzania

$\beta_{0} \quad$ Represents a constant factor

$\sum_{j=1}^{n} \beta_{1} x_{1}$ Represents an independent variable, the implementations of the best practice in repayment in the Pre

$\sum_{j=1}^{n} \quad$ College preparations $(B)$

$\begin{array}{ll}\sum_{j=1}^{n} \beta_{2} x_{2} & \text { Represents an indepe } \\ \sum^{n} \beta_{3} x_{3} & \text { College period }(C)\end{array}$

$\sum_{j=1}^{n} \beta_{3} x_{3} \quad \begin{array}{ll}\text { Represents an independent } \\ \text { After College period }(D)\end{array}$

$\varepsilon_{i} \quad$ Represents an error term. 
All assumptions of the linear regression model were considered after verification for example the homoscedasticity, normality, linearity and independence.

\section{Findings and Discussion}

The main of this study is to determine on whether the implementations of the best practice in repayments in the pre college preparation, the in college period and the after college period has an influence in the increasing collections of the due students loans. In order to achieve the desired answers to the questions the following hypotheses were used to guide this study:

$H_{l}$ Implementations of the best practices in repayment in the pre college preparation increases collections of the due students' loans.

$\mathrm{H}_{2}$ Implementations of the best practices in repayment in the in college period increases collections of the due students' loans.

$H_{3}$ Implementations of the best practices in repayment in the after college period increases collections of the due students' loans.

300 questionnaires were distributed to the targeted respondents, where by only 267 respondents returned the filled questionnaires which is approximately $89 \%$ response rate which a good response. Hence the study considered a sample of 267 respondents.

\subsection{Sample Characteristics and Reliability Test}

\subsubsection{Sample Characteristics}

From the findings the following conclusions from the sample characteristics were drawn (a) more than three quarter of the respondents in the pre college category were at the age between 18 and 24 while respondents from the in college category at this age group form only $71 \%$ of the total respondents. Post college respondents at the age between 25 and 30 forms nearly a half of the total respondents in this category. This is a fair age distribution among these categories of the respondents, the researcher expected to find more respondents in the age of 18-24 because this is a schooling age, also more respondents at the age of 25-30 in the post college category because these are respondents in either grace period or in repayment period, refer Table 10, 11 and 12 (Appendix II). (b) Gender distribution among the respondents were fairly represented, more than half of the respondents were male while females form only $47 \%$. Males were expected to be more than female in this study due to the education system in Tanzania which is in favour of males from pre college level, in college and in the after college. Female are still lagging behind in term of education in Tanzania due to traditions which hinder females from attaining higher education for example the believe that female are there to attend domestics issues like cooking and washing etc. (refer Table 13, Appendix II).

(b) The population was fairly distributed in term of professional, this is because it is expected by the researcher to find more students in Business Management studies which is represented by $1 / 5$ of the total population, followed by almost $18 \%$ of students in the Education Science and Mathematics which are priority programmes in term of loans provision hence it attracts more students, $16 \%$ of the total population were representing students from Engineering studies, and the remaining percentages were evenly distributed among other professions, refer Table 14 (Appendix II). (c) more than half of the respondents were from Kinondoni district and the remaining percentage were evenly distributed among the two districts the Temeke and Ilala, the researcher expected to find more respondents from Kinondoni districts because the district has more secondary schools, Universities as well as more organizations which attracts a lot of graduates who are loan beneficiaries, refer Table 15 (Appendix II). (d) Nearly half of the respondents in the after college category were from DUCE staff, and 1/5 of the respondents is formed by respondents from HESLB staff, the remaining percentages were evenly distributed among TPB, NBC and others, the population was fairly represented because it was expected to find more respondents who are employees at DUCE as it is a higher learning institution which employ more fresh graduates who are loan beneficiaries in either grace period or on repayment, refer Table 16 (Appendix II). (e) more than 1/3 of the respondents were from IFM for the in college students' category, where by $1 / 5$ of the respondents were from DIT, $1 / 4$ of the respondents were the respondents from DUCE and the remaining percentages were evenly distributed among UDSM, CBE. The results were fairly representing the population because during the data collection exercise most universities were at their midterm break, at IFM most students were there attending their supplementary examination so it was easy for them to fill in most of the questionnaires. (f) Pre College respondents were almost evenly distributed among the secondary schools selected refer Table 18 (Appendix II). 


\subsubsection{Reliability Tests}

Cronbach test model was used to test reliability of the constructs, in this study four reliability tests were conducted for repayment practices in the pre college preparation, the in college period, the after college period and the increased collections of the due students' loans as shown in Table 19 in Appendix II. The internal consistency of data based on the average inter item correlation was tested and the results is as presented in Table 19 in Appendix II. Normally good reliability ranges from 0.7 and above (Cronbach \& Richard, 2004). The results of this analysis indicate that reliability tests results into alpha coefficients which exceed 0.7 which is a good reliability coefficient. The greater the value of alpha the more the reliability of the construct, therefore best repayment practices in the pre college preparation in this study is more reliable, followed by the best practice in repayment in the in college period, then the last variable is the best practice in repayment in the after college period, refer Table 19 in Appendix II.

\subsection{Hypotheses Testing}

Data collected were used to test empirically the hypotheses developed from the literature reviewed. This study has three hypotheses and three constructs which are the implementations of the best practice in repayment in the pre college preparation, the implementations of the best practice in repayment in the in college period and the implementations of the best practices in repayment in the after college period. Table 6 indicates the results of the correlation analysis which measure the strength and directions of the association between the independent variables. The predictor variables were proved to be positively related and significantly correlated as shown in Table 6.

Table 6. Correlations

\begin{tabular}{lllll}
\hline & & AVRB & AVRC & AVRD \\
\hline \multirow{2}{*}{ AVRB } & Pearson Correlation & 1.000 & $.124^{* *}$ & $.056^{* *}$ \\
& Sig. (2-tailed) & & .000 & .000 \\
& $\mathrm{~N}$ & 103 & 104 & 60 \\
& Pearson Correlation & $.124^{* *}$ & 1.000 & $.007^{* *}$ \\
AVRC & Sig. (2-tailed) & .000 & & .000 \\
& $\mathrm{~N}$ & 103 & 104 & 60 \\
& Pearson Correlation & $.0672^{* *}$ & $.0 .008^{* *}$ & 1.000 \\
AVRD & Sig. (2-tailed) &. &. & \\
& $\mathrm{N}$ & 103 & 104 & 60 \\
\hline
\end{tabular}

** Correlation is significant at the 0.01 level (2-tailed).

Source: Field data (2015)

Where:

AVRB Average of items under the implementations of the best

Practice in repayment in the pre college

Preparation

AVRC Average of items under the implementations of the best

Practice in repayment in the in college period

AVRD Average of items under the implementations of the best

Practice in repayment in the after college period

In the further analysis multiple regression technique were used to analyse the strength of relationship between the implementations of the best practice in repayment in the pre college preparation, the implementations of the best practice in repayment in the in college period, the implementations of the best practice in repayment in the after college period and the increased collections of the due students' loans. The results in Table 7 indicates that 
there is a strong relationship between independent variable and the dependent variable $\left(R^{2}>0.5\right)$, that is the independent variables accounted for about $73.3 \%$ of the variance on the increased collections of the due students' loans, and the remaining $26.7 \%$ is explained by other variables not explained by the model. Table 7 also indicates the value of Durbin Watson which is 1.770, this value indicates a strong relationship between the implementations of the best practice in repayment in the pre college preparation, the implementations of the best practice in repayment in the in college period, the implementations of the best practice in repayment in the after college period and the increased collections of the due students' loans. The accepted range for Durbin Watson is between 1.5-2.00 (Durbin, 1951) hence the results showed that there is a statistical evidence that the error terms are not positively correlated.

Table 7. Model summary

\begin{tabular}{lllllll}
\hline Model & $\mathrm{R}$ & R Square & $\begin{array}{l}\text { Adjusted } \\
\text { Square }\end{array}$ & $\begin{array}{l}\text { Rtd. Error of the } \\
\text { Estimate }\end{array}$ & $\begin{array}{l}\text { Durbin } \\
\text { Watson }\end{array}$ \\
\hline 1 & .856 & .733 & .728 & 1.154 & 1.770 \\
\hline
\end{tabular}

Source: Field data (2015)

Table 8 represents the ANOVA results which were obtained by the researcher, it indicate that the model results were statistically significant because the significant value is 0.000 hence the value is less than 0.05 also its $F$ value is lying in a location that supported the positive impact. As a rule of thumb the model is statistically significant when the value of $\mathrm{p}$ is less than 0.05 i.e., $\mathrm{p}<0.05$. Therefore there is a significant relationship between implementations of the best practice in repayment in the pre college preparation, best practice in repayment in the in college period, best practice in repayment in the after college period and the increased collections of the due students' loans. In this model independent variables explained much of the variation in the dependent variables.

Table 8. ANOVA results

\begin{tabular}{llllll}
\hline Model & Sum of Squares & df & Mean Square & F & Sig. \\
\hline Regression & 14.588 & 5 & 2.918 & 6.657 & $.000^{\mathrm{b}}$ \\
1 Residual & 42.953 & 98 & .438 & & \\
Total & 57.541 & 103 & & & \\
\hline
\end{tabular}

Source: Field data (2015)

a. Dependent Variable: AVRE

b. Predictors: (Constant), AVRB, AVRC, AVRD

\subsubsection{Testing of Hypothesis 1}

$H_{I}$ Implementations of the best practices in repayment in the pre college preparation increases collection of the due students'loans.

This study attempted to test if there were any relationship between the implementations of the best practice in repayment in the pre college preparation, implementations of the best practice in repayment in the in college period, implementations of the best practice in repayment in the after college period and the increased collections of the due students' loans. The test was based on the parents, prospective loans beneficiaries and students' loans beneficiaries from 5 secondary schools (Azania, Zanaki, Jangwani, Mbezi, Makongo), 5 universities (UDSM, DUCE, CBE, IFM, DIT) and 4 Organizations (HESLB, TPB, NBC, \& DUCE Academic staff). Table 9 indicates that, the regression coefficient $(\beta)$ for the implementations of the best practice in repayment in the pre college preparation (AVRB) is 0.495 which implies that for every unit change in the implementations of the best practice in repayment in the pre college preparation there is 0.495 times change in the degree of the increased collections of the due students' loans in the same direction (increase or decrease) and $\mathrm{p}=0.000 ; \mathrm{p}<0.05$, as long as $\mathrm{p}$ value is less than $0.05, \mathrm{H}_{1}$ is accepted and the null hypotheses can be rejected.

Therefore at $95 \%$ level of confidence, it was concluded that there is a positive relationship between the 
implementations of the best practice in repayment in the pre college preparation and the increased collections of the due students' loans, hence hypothesis 1 is confirmed to be true, the implementations of the best practice in repayment in the pre college preparation increases collection of the due students' loans.

Table 9. Coefficients

\begin{tabular}{|c|c|c|c|c|c|c|c|}
\hline \multirow[b]{2}{*}{ Model } & \multicolumn{2}{|c|}{$\begin{array}{l}\text { Unstandardized } \\
\text { Coefficient }\end{array}$} & \multicolumn{2}{|l|}{$\begin{array}{l}\text { Standardized } \\
\text { Coefficients }\end{array}$} & \multirow[b]{2}{*}{ Sign } & \multicolumn{2}{|c|}{ Collinearity Statistics } \\
\hline & 及 & Std Error & $\beta$ & $\mathrm{t}$ & & Tolerance & VIF \\
\hline Constant & 1.372 & .281 & & 4.880 & 0.000 & & \\
\hline AVRB & .268 & .054 & .495 & 4.990 & 0.000 & .748 & 1.337 \\
\hline AVRC & .234 & .090 & .275 & 2.612 & .010 & .686 & 1.459 \\
\hline AVRD & .016 & .19 & .113 & .818 & .417 & .783 & 1.276 \\
\hline
\end{tabular}

Source: Field data (2015)

a. Dependent variable: AVRE

\subsubsection{Testing of Hypothesis 2}

$\mathrm{H}_{2}$ Implementations of the best practices in repayment in the in college period increases collections of the due students'loans.

Table 9 indicates that, the regression coefficient $(\beta)$ for the implementations of the best practice in repayment in the in college period (AVRC) is 0.275 which implies that for every unit change in the implementations of the best practice in repayment in the in college period there is 0.275 times change in the degree of the increased collections of the due students' loans in the same direction (increase or decrease) and $p=0.000 ; p<0.05$, as long as $p$ value is less than $0.05, \mathrm{H}_{2}$ is accepted and the null hypotheses can be rejected. Therefore at $95 \%$ level of confidence, it was concluded that there is a positive relationship between, implementations of the best practice in repayment in the in college period and the increased collections of the due students' loans, hence hypothesis 2 is confirmed to be true, the implementations of the best practices in repayment in the in college period increases collections of the due students' loans.

\subsubsection{Testing of Hypothesis 3}

$\mathrm{H}_{3}$ Implementations of the best practices in repayment in the after college period increases collections of the due students'loans.

Table 9 indicates that, the regression coefficient $(\beta)$ for the implementations of the best practice in repayment in the post college period (AVRD) is 0.113 which implies that for every unit change in the implementations of the best practice in repayment in the post college period there is 0.113 times change in the degree of the increased collections of the due students' loans in the same direction (increase or decrease) and $p=0.000 ; p<0.05$, as long as $\mathrm{p}$ value is less than $0.05, \mathrm{H}_{3}$ is accepted and the null hypotheses can be rejected. Therefore at $95 \%$ level of confidence, it was concluded that there is a positive relationship between, implementations of the best practice in repayment in the post college period and the increased collections of the due students' loans, hence hypothesis 3 is confirmed to be true, the implementations of the best practices in repayment in the post college period increases collections of the due students' loans.

\section{Conclusions and Recommendations}

\subsection{Conclusions}

Increasing collections of the due students' loans is an important aspect in ensuring the sustainability of the students' loans scheme in Tanzania. In this study the research concerning the investigation of the influence of the implementations of the best practices in repayments in the pre college preparation, the in college period and in the after college period were conducted, among the practices includes presentations to promote value of education, national campaign to promote education from secondary level both nationally and locally, organization of college fair to educate on loan repayment and employees education at their work place, presence of students financial aid offices, entry and exit counselling sessions during the in college period as well as maintenance of the regular contacts with borrowers during the after college period. 
The findings of this study reveal that implementations of the best practice in repayment in the pre college preparation has a positive effect to the increased collections of the due students' loans hence sustainability of the students' loans scheme. The pre college preparation is the most important stage in the higher education cycle because it has an effect at the later stage of students' loans repayment. Parents, prospective loans beneficiaries and the society need to be educated on the important of the higher education, how to manage students' loans and repayments. At this stage parents, prospective loans beneficiaries and society in general can be created to adopt the credit culture by having plan on education for their children or themselves. Practices in this stage among others include national campaign to promote education and employee's education at their work place.

It was further concluded that the implementations of the best practices in repayment in the in college period has an influence in the increased collections of the due students' loans. This period is very important in enhancing repayment of the students' loans as it is the period in which the actual loan provision is being practices, much attention is also needed here, students need to be attached to students' financial aid for more education and communications concerning loan provision, drop out has to be interviewed on how they will handle the loan provided to them after they have dropped also loan provision contracts has to be read careful before they are filled.

Furthermore the results revealed a significant relationship between the implementations of the best practices in repayment in the after college period and the increased collections of the due students' loans. The period consists of the graduates mostly employees or self employed graduates either in grace period or in repayment. It is believed that after being educated and taken care in the pre college preparation and the in college period, graduates are now aware of their obligation to repay back the students' loans given when they were in college. Practices like maintenance of the regular contacts with borrowers and setting of repayment dates at the pay day are expected to facilitate more repayment and hence increased collections of the due students' loans.

Therefore all the three independent variables have been proved by the findings to have an influence on the increased collections of the due students' loans though at different magnitudes. The implementations of the best practice in repayment in the pre college preparation contribute more to the dependent variable hence it rank the first variable in this study, the second variable is the implementations of the best practice in repayment in the in college period and the last one is the implementations of the best practice in repayment in the after college period. It is supported by various researchers that at the after college period the graduates has enough knowledge on how to deal with repayment and its importance therefore once the best practices are well implemented in the pre college period and in the in college period, then there will be less impact in the after college period (Alberto et al., 2007).

It was further concluded that in additional to the implementations of the best practices to increase collections of the due students' loan HESLB should also change some of its policies which hinder the attainment of the increased collections for example (1) while current students' loans are charged an interest of $6 \%$ per annum, the rate is below the prevailing market interest rate which is ranging between $15 \%$ and $18 \%$ (BOT, 2015); (2) Monthly loan repayment rate at $8 \%$ of the beneficiaries' salaries is too low for the Board to recover loans in time. Also, the 10 years maximum period allowed for repayment is too long for the Board to recover the same value of money from loanees due to changes in the value of money over time.

\subsection{Recommendations}

It is recommended that the Higher Education Students' Loans Board (HESLB) should ensure that the best practices are being implemented in the pre college preparations, the in college period and in the after college period i.e., by educating parents, prospective loans beneficiaries at secondary schools, employees and the general public, conducting of exit and entry interview to the college students as well reminding of students' loan beneficiaries of the end of their grace period and repayment start date.

The study also recommends that apart from enhancing implementations of the best practices in all stages (the pre college preparations, the in college period and the after college period). The Government should find the alternative financing sources for higher education in addition to the current government funding through HESLB The Government should encourage higher education stakeholders from the private sector, development organizations and other non governmental institutions (local and international) such as financial, religious and other institutions to invest in education, so as to meet the growing demand for higher education which is evidenced by the gap between allocations and applications.

It is also recommended that, in additional to the proper implementations of the best practices in the pre college preparation, the in college period and the after college period, HESLB should have a sound financial management by charging interest on loan at slightly less than the prevailing market interest rate value to take 
care of inflation persisting within the country, the interest rate charged should be raised from the current rate of $6 \%$ to at least between $15 \%$ and $18 \%$ which is a current prevailing market interest rate as advocated by BOT (2015). HESLB to revise the rate by increasing the proportion of salaries to be remitted to the Board since loan Repayment at $8 \%$ of the students' loans beneficiaries' salaries/income is too low. Also HESLB has to reduce the maximum repayment period from 10 years to say 5 years so as to cope with the changes in the value of money.

It was recommended that in order to facilitate the implementation of the best practice in repayment in the after college period, the government should speed up the issuance of national IDs, which is expected to play a big role in tracing loan beneficiaries for repayment purposes. Also, it will facilitate verification of information submitted during loan application process

It was further recommended that HESLB to overcome all the challenges hindering the implementations of the best practices in repayment for example, in adequate co operations from some of the employers have to be dealt with by formulation of legislation to enforce employers' compliance to loan repayment requirements.

\section{Limitations and Direction for Future Research}

Proper implementation of the best practices in repayment in the pre college preparation, the in college period and in the after college period were considered in this study as the only factor influencing collection of the due students' loans. There are some literatures which revealed that there are other factors affecting increased collections such as the characteristics attained by the students' loan borrowers after graduation (termed as the post college measures), these includes characteristics such as highest degree attained, income and marital status of a borrowers, therefore future studies should include these factors which remained undone in this research.

This study focused only on the universities/colleges, secondary schools and organizations within Dar es salaam city, this is because it was believed by the researcher that best results could be obtained from Dar es salaam because the universities and organizations in Dar es salaam city consists of more students' loans beneficiaries compared to other regions in Tanzania. Therefore future studies has to expand more and cover other regions of the country to cover more universities/colleges, secondary schools and organizations to make the results a better representation of the whole country, also this will increase diversity of the results to be applicable to other countries.

Future studies should expand to include other factors not explained by this model, it was explained that increase in the collection of the due students' loans has been affected at only $73.3 \%$ and around $26.7 \%$ factors were not explained by the model. Therefore other factors than the implementations of the best practice in repayment in the pre college preparation, in college period and after college period need to be considered for example factors such as the highest degree attained and the income need to be explored.

The literature presented in this study indicates that most of the researches concerning the implementations of the best practices in repayments were done in developed countries and little has been done in developing countries. Therefore in the future studies researchers should be encouraged to put more emphasis on assessment of the implementations of the best practices in repayments as a way to increase collections of the due students' loans in developing countries like Tanzania.

\section{Acknowledgements}

My special thanks should go to Mr. Simon Ngalomba who is a Lecture at University of Dar es salaam (School of Education) for the material contribution and encouragement in developing this article, I would like to thank also Mr. Venance Ntiyalundura my co worker at the Higher Education Students' Loans Board (HESLB) for providing me with various valuable information I required. I feel obliged to Ms. Anna Raphael who was my research assistance for the whole period of data collections and data entry for her endless support in developing this article. Special thanks should go to Mr. Josephat Machiwa Loan Officer at Dar es salam University College of Education for the uncomparable cooperation he has shown during data collection exercise. Lastly special thanks should go to students' loans beneficiaries from HESLB staff, Tanzania Postal Bank (TPB), National Bank of Commerce (NBC), DUCE staff, UDSM, CBE, IFM, DUCE, DIT and prospective students' loans beneficiaries from AZANIA Secondary school, ZANAKI Secondary school, JANGWANI secondary school, MBEZI BEACH Secondary school and MAKONGO Secondary school by furnishing me with valuable information through filling questionnaires given to them. 


\section{References}

Alberto et al. (2007). Predictive Modelling for collections and Refinancing. First Collections Summit, Credit Management Solution. Buenos Aires, Argentina.

Amrhein, M. et al. (2000). Ensuring Student Loan Repayment. A national Handbook of Best Practices, Based on the Student Loan Repayment Symposium October, 2-4, 2000.

Bank of Tanzania. (2015). Tanzania interest rate/2002-2015/Data/Chat/Calendar/Forecast. Retrieved from $\mathrm{http} / /$ tradingeconomics.com/Tanzania/lending-interest-rate-percent-wb-d.

Brachfield, P. J. et al. (2002). Recovering and negotiating with delinquent Clients. Barcelona: Ediciones Gestion 2000, S. A.

Brachfield, P. J. et al. (2004). Cornering unpaid debtors: Recovering unpaid debts through effective negotiations with delinquent Clients. Barcelona: Ediciones Gestion, 2000, S. A.

Center for the Study of Financial Innovation-CSFI. (2008). "Microfinance Banana Skins, Risk in a bloomin industry".

Cronbach, L., \& Richard, J. (2004). My Current Thoughts on Coefficient Alpha and Successor Procedures. Educational and Psychological Measurement, 64(3), 391-418. http://dx.doi.org/10.1177/0013164404266386

Devaney, \& Patricia, L. (2006). "Bringing Pro-Consumer Ideals to the Client”. ACCION, Monograph, No. 14, ACCION International, May, 2006.

Durbin, J., \& Watson, G. (1951). Testing for Serial Correlation in Least Squares Regression, II. Biometrika, 38, 159-179. http://dx.doi.org/10.2307/2332326

Herr, E., \& Burt, L. (2005). Predicting student loan default for the University of Texas at Austin. Journal of Student Financial Aid, 335(2), 27-47.

HESLB. (2004). Act number 9 of 2004 CAP 178. Dar es salaam, Higher Education Students Loans Board.

HESLB. (2014a). Corporate strategic plan 2014-2017. Dar es salaam, Higher Education Students Loans Board.

HESLB. (2015a). Report on Local Undergraduate and local Postgraduate Applications and Allocations. Retrieved from the Loan Management System (LMS), on 10th June, 2015.

HESLB. (2008). Loan Allocation and Disbursement Mannual. HESLB, Loan Allocation and Disbursement. Dar es salaam: Higher Education Students' Loans Board.

HESLB. (2014b). Loan Allocation and Disbursement Report for the period ending $31^{\text {st }}$ June, 2014. HESLB, Loan Allocation and Disbursement. Dar es salaam: Higher Education Students' Loans Board.

HESLB. (2014c). Cummulative Loan Repayment Report up to $31^{\text {st }}$ June, 2014. HESLB, Loan Repayment and Recovery. Dar es salaam: Higher Education Students' Loans Board.

HESLB. (2014d). Cummulative Loan Repayment Report up to $31^{\text {st }}$ December, 2014. HESLB, Loan Repayment and Recovery. Dar es salaam: Higher Education Students' Loans Board.

HESLB. (2015b). Cummulative Loan Repayment Report up to $31^{\text {st }}$ December, 2014. HESLB, Loan Repayment and Recovery. Dar es salaam: Higher Education Students' Loans Board.

HESLB. (2015c). Loan Allocation and Disbursement Report for the period ending $31{ }^{\text {st }}$ March, 2015. HESLB, Loan Allocation and Disbursement. Dar es salaam: Higher Education Students' Loans Board.

HESLB. (2015d). Published guidelines ad criteria for granting loans in academic year 2014/2015. Loan allocations and disbursements. Dar es salaam: Higher Education Students' Loans Board.

Ishengoma, J. M. (2008). The paper presented at the University Leaders' Forum: Next Generation of Academics. Accra, Ghana, November $22^{\text {nd }}-25^{\text {th }} 2008$.

Ishengoma, J. M. (2004). Cost Sharing and Participation in Higher Education in Sub Saharan Africa: The Case of Tanzania (Doctoral dissertation). State University of New York at Buffalo.

Johnstone, D. B. (2009). An International perspective of the financial fragility of higher education institutions and systems. Leading stressed colleges and Universities to excellence, 31-34.

Misino, D. J. (2004). Negotiate and Win, Unbeatable Real-World Strategies from the NYPD'S Top negotiator. New York: McGraw Hill. 
Mori, T. et al. (2006). Training for Banco Solidario - Collections unit in Quito and Guayaquil cities. Ecuador, 11-16.

Msolla, P. (2007). Issues of Higher Education in Tanzania. Comments at the Joint Japan-World Bank Graduate Scholarship program Regional Conference in Dar es Salaam.

Nimal, A., \& Fernando. (2008). Managing Microfinance Risks-Some observations and Suggestions. Asian Development Bank, Asia.

Nyahende, V. R. (2013a). The Influence of Students' loans Borrowers' Characteristics on Default rate in Tanzania. The Journal of Higher Education Studies, 3(4), 26-49. http://dx.doi.org/10.5539/hes.v3n4p26

Nyahende, V. R. (2013b). The Success of Students' Loans in Financing Higher Education in Tanzania. The Journal of Higher Education Studies, 3(3), 47-61. http://dx.doi.org/10.5539/hes.v3n3p47

Rial, A. et al. (2004). Best practice in Consumers' collections. London: VRL Publishing, Ltd.

Saunders, M., Lewis, P., \& Thornhill, A. (2007). Reseach methods for Business students (4th ed.). New York, NY: Prentice Hall.

Tanzania Commission for Universities. (2015). The list of higher learning Institutions in Tanzania based on ownership, TCU. Retrieved from www.http://tcu.go.tz/Institutions.

Woodhall, M. (2007). Funding Higher Education; The contribution of Economic Thinking to Debate and policy development. Washington, D.C.: World Bank.

XE Currency API. (2015). XE Currency Converter. Exchange rate 1USD = TZS 2,149.45. Retrieved from http://www.xe.com/Currency Converter/ Convert/?Amo.

\section{Appendix A}

\section{Questionnaires}

The main aim of this questionnaire is to get information on the Implementations of the Best Practices in Repayment, the way to Improve Collection of the due Students' Loans in Tanzania. The questionnaire specifically covers students who are loans beneficiaries from the selected universities, the graduated students' loan beneficiaries who are employed in the selected companies/organizations and prospective students of Higher Learning Institutions from the selected secondary schools. The results of this research will be used solely for academic purposes. You are requested to complete this questionnaire promptly as directed to enable timely accomplishment of the study, kindly note that the information provided will be treated as a confidential and it will in no way be conveyed to any other person.

SECTION A: General Information, Please fill in the blank spaces provided.

(1) (a) Age (Pre college students)
36-40 yrs [ ] 41 and above [ $]$

(2) Gender Male [ ] Female [ ]

(3) Professional Business Management [ ] General Science (Specify)[ ] Law [ ] Engineering [ ] Medicine [ ] Agriculture [ ] Arts [ ] IT \& Computer Science [ ] Finance \& Accounting [ ] Social Science [ ] Education Science \& Mathematics [ ] Education Others [ ] Other (Specify) [ ]

(4) District

(5) In which University/College do you belong or studied among the ones enlisted? (Please tick)

\begin{tabular}{|l|l|l|l|l|}
\hline UDSM & DUCE & CBE & IFM & DIT \\
\hline & & & & \\
\hline
\end{tabular}


(6) In which Company/Organization do you belong among the ones enlisted? (Please tick)

\begin{tabular}{|l|l|l|l|l|}
\hline HESLB & TPB & NBC & DUCE STAFF & OTHERS \\
\hline & & & & \\
\hline
\end{tabular}

(7) In which Secondary school do you belong among the ones enlisted? (Please tick)

\begin{tabular}{|l|l|l|l|l|}
\hline AZANIA & ZANAKI & JANGWANI & MBEZI BEACH & MAKONGO \\
\hline & & & & \\
& & & & \\
\hline
\end{tabular}

For Section B, C, D and E please circle correctly

SECTION B: Pre college/university Preparation (Pre college/university Students)

1 = Fair, 2 = Average, 3 = Good, $4=$ Very good, 5 = Excellent

(1) Early education concerning students' loans and repayment is given using the existed models (groups) in schools (secondary schools)
Not at all
2
3
4
5
To a great extend.

(2) Presentations are made to promote the value of education, the case study from some beneficiaries on how higher education has increased their level of income
Not at all
2
3
4
5
To a great extend

(3) National campaign are made using national, regional and local with the view of promoting post secondary school opportunities, students' loans and repayments.
Not at all
1
2
3
4
5

To a great extend.

(4) College fair are organized at the ordinary and high school level to educate students about students' loans and repayments.
Not at all
1
2
3
4
To a great extend.

(5) Employees are educated at their work place about post secondary education opportunities, students' loans and repayment so that they can plan for their children's future.

$$
\begin{array}{lllll}
\text { Not at all } & 1 & 2 & 3 & 4
\end{array}
$$

To a great extent.

\section{SECTION C: In College Period (Students' Loans beneficiaries)}

\section{1 = Fair, 2 = Average, 3 = Good, 4 = Very good, 5 = Excellent}

(1) Loan beneficiaries are attached to students' financial aid office (loans offices)
Not at all$$
1
$$
2
To a great extend.

3

4

5

(2) Entrance and exit counseling sessions are conducted to remind students/parents/guardian of their obligations to repay the loans given.
Not at all 1
2
3
4
5
To a great extend

(3) Students are reading carefully the loan provision contracts before filling and signing them to avoid misinterpretations and disputes when loans are due for repayments
Not at all
1
2
To a great extend.

3

4 
(4) Provision of exit interview to dropout to avoid the risk of defaulting, by helping them prepare for future plans and review of repayment obligations and options
Not at all
1
2
3
4
5
To a great extend.

(5) Appointment of default specialist to persuade students' borrowers to repay their loans timely.
Not at all
1
2
3
4

To a great extent.

\section{SECTION D: After College (Graduated Students/employees)}

1 = Fair, 2 = Average, 3 = Good, 4 = Very good, 5 = Excellent

(1) Students' loans beneficiaries are reminded on the start repaying date 2 months before the end of the grace period
Not at all
1
23
4
5 To a great extent.

(2) Regular contacts with borrowers are maintained to know their location.
Not at all
123
4
5
To a great extent.

(3) Borrowers on grace period are given reminder notice telling them when to start repaying their loan and at what rate
Not at all
123
4
5
To a great extent.

(4) Establishment of the contacts with drop out and re involving them back to school after knowing the reasons for their drop out in reducing chanced to defaulting.
Not at all
$\begin{array}{lll}1 & 2 & 3\end{array}$
4
5
To a great extent.

(5) Repayment date to be set on the pay day to avoid inconveniences to borrowers
Not at all
$\begin{array}{lll}1 & 2 & 3\end{array}$
4
5
To a great extent.

\section{SECTION E: Improvement in the Students' Loans due Collection}

\section{$1=$ Fair, 2 = Average, $3=$ Good, $4=$ Very good, $5=$ Excellent}

(1) HESLB is employing enough strategies to ensure the increased collections of the due students' loans granted to beneficiaries since 1994.
Not at all
1 23
4
5 To a great extent.

(2) HESLB is increasing collections of the due students' loans by having a committed management in loan recovery.
Not at all 1
23
4
5 To a great extent.

(3) A substantial part of the HESLB administration's costs is covered by the amount collected from the due students' loans.
Not at all
12
3
4
5
To a great extent.

(4) Mechanism used by HESLB to trace the loan beneficiaries, so as to increase collections of the due students' loans are effective.
Not at all
12
23
$4 \quad 5$
To a great extent.

(5) HESLB policies and procedures for collecting the already issued funds are effective.
Not at all 1
23
4
5
To a great extent.

\section{SECTION F: Others}

1. What are the other best practices in repayment do you consider relevant to increase collection of the due students' loans?
(a) In Pre college preparation
(1)
(2)
(3) 
(b) In college period

(1)

(2)

(3)

(b) After college (grace period \& Repayment)

(1)

(2)

(3)

2. Other advice to the Board (HESLB) if any, for strengthening and improvement of the due students' loans collections

3. What are the challenges affecting the Board from increasing collection of the due students' loans?..

4. Any comments considered necessary to HESLB.

THANK YOU VERY MUCH FOR YOUR CO-OPERATION

\section{Appendix B}

Table B1. Age PreCollege

\begin{tabular}{llllll}
\hline & & Frequency & Percent & Valid Percent & $\begin{array}{l}\text { Cumulative } \\
\text { Percent }\end{array}$ \\
\hline \multirow{4}{*}{ Valid } & 15-17yrs & 1 & .4 & 1.0 & 1.0 \\
& $18-24 \mathrm{yrs}$ & 97 & 36.3 & 94.2 & 95.1 \\
& $25-30 \mathrm{yrs}$ & 5 & 1.9 & 4.9 & 100.0 \\
& Total & 103 & 38.6 & 100.0 & \\
Missing & System & 164 & 61.4 & & \\
Total & & 267 & 100.0 & &
\end{tabular}

Source: Field data (2015)

Table B2. Age InCollege

\begin{tabular}{llllll}
\hline & & Frequency & Percent & Valid Percent & $\begin{array}{l}\text { Cumulative } \\
\text { Percent }\end{array}$ \\
\hline \multirow{4}{*}{ Valid } & 18-24yrs & 74 & 27.7 & 71.2 & 71.2 \\
& $25-30 y r s$ & 29 & 10.9 & 27.9 & 99.0 \\
& $36-40 y r s$ & 1 & .4 & 1.0 & 100.0 \\
\multirow{4}{*}{ Missing } & Total & 104 & 39.0 & 100.0 & \\
Total & System & 163 & 61.0 & & \\
\hline
\end{tabular}

Source: Field data (2015) 
Table B3. Age PostCollege

\begin{tabular}{llllll}
\hline & & Frequency & Percent & Valid Percent & $\begin{array}{l}\text { Cumulative } \\
\text { Percent }\end{array}$ \\
\hline \multirow{6}{*}{ Valid } & $18-24 \mathrm{yrs}$ & 5 & 1.9 & 8.3 & 8.3 \\
& $25-30 \mathrm{yrs}$ & 25 & 9.4 & 41.7 & 50.0 \\
& $31-35 \mathrm{yrs}$ & 17 & 6.4 & 28.3 & 78.3 \\
& $36-40 \mathrm{yrs}$ & 11 & 4.1 & 18.3 & 96.7 \\
& $41 \&$ above & 2 & .7 & 3.3 & 100.0 \\
Missing & Total & 60 & 22.5 & 100.0 & \\
Total & System & 207 & 77.5 & & \\
\hline
\end{tabular}

Source: Field data (2015)

Table B4. Gender

\begin{tabular}{llllll}
\hline & & Frequency & Percent & Valid Percent & $\begin{array}{l}\text { Cumulative } \\
\text { Percent }\end{array}$ \\
\hline \multirow{3}{*}{ Valid } & Male & 140 & 52.4 & 52.4 & 52.4 \\
& Female & 127 & 47.6 & 47.6 & 100.0 \\
& Total & 267 & 100.0 & 100.0 & \\
\hline
\end{tabular}

Source: Field data (2015)

Table B5. Profession

\begin{tabular}{|c|c|c|c|c|c|}
\hline & & Frequency & Percent & Valid Percent & $\begin{array}{l}\text { Cumulative } \\
\text { Percent }\end{array}$ \\
\hline \multirow{13}{*}{ Valid } & Business Management & 35 & 13.1 & 21.3 & 21.3 \\
\hline & General Science & 2 & .7 & 1.2 & 22.6 \\
\hline & Law & 1 & .4 & .6 & 23.2 \\
\hline & Engineering & 27 & 10.1 & 16.5 & 39.6 \\
\hline & Agriculture & 1 & .4 & .6 & 40.2 \\
\hline & Arts & 2 & .7 & 1.2 & 41.5 \\
\hline & IT \& Computer Science & 8 & 3.0 & 4.9 & 46.3 \\
\hline & Finance\& Accounting & 25 & 9.4 & 15.2 & 61.6 \\
\hline & Social Science & 5 & 1.9 & 3.0 & 64.6 \\
\hline & Education others & 21 & 7.9 & 12.8 & 77.4 \\
\hline & $\begin{array}{l}\text { Education Science } \\
\text { and Mathematics }\end{array}$ & 29 & 10.9 & 17.7 & 95.1 \\
\hline & Others & 8 & 3.0 & 4.9 & 100.0 \\
\hline & Total & 164 & 61.4 & 100.0 & \\
\hline Missing & System & 103 & 38.6 & & \\
\hline Total & & 267 & 100.0 & & \\
\hline
\end{tabular}

Source: Field data (2015) 
Table B6. Regional/District

\begin{tabular}{llllll}
\hline & & Frequency & Percent & Valid Percent & $\begin{array}{l}\text { Cumulative } \\
\text { Percent }\end{array}$ \\
\hline \multirow{4}{*}{ Valid } & kinondoni & 138 & 51.7 & 51.7 & 51.7 \\
& Temeke & 64 & 24.0 & 24.0 & 75.7 \\
& Ilala & 65 & 24.3 & 24.3 & 100.0 \\
& Total & 267 & 100.0 & 100.0 & \\
\hline
\end{tabular}

Source: Field data (2015)

Table B7. Company/organization name

\begin{tabular}{llllll}
\hline & & Frequency & Percent & Valid Percent & $\begin{array}{l}\text { Cumulative } \\
\text { Percent }\end{array}$ \\
\hline \multirow{4}{*}{ Valid } & HESLB & 14 & 5.2 & 23.3 & 23.3 \\
& TPB & 5 & 1.9 & 8.3 & 31.7 \\
& NBC & 8 & 3.0 & 13.3 & 45.0 \\
& DUCE STAFF & 28 & 10.5 & 46.7 & 91.7 \\
& OTHERS & 5 & 1.9 & 8.3 & 100.0 \\
\multirow{2}{*}{ Missing } & Total & 60 & 22.5 & 100.0 & \\
Total & System & 207 & 77.5 & & \\
\hline
\end{tabular}

Source: Field data (2015)

Table B8. University/college

\begin{tabular}{llllll}
\hline & & Frequency & Percent & Valid Percent & $\begin{array}{l}\text { Cumulative } \\
\text { Percent }\end{array}$ \\
\hline \multirow{4}{*}{ Valid } & UDSM & 1 & .4 & 1.0 & 1.0 \\
& DUCE & 28 & 10.5 & 26.9 & 27.9 \\
& CBE & 17 & 6.4 & 16.3 & 44.2 \\
& IFM & 34 & 12.7 & 32.7 & 76.9 \\
\multirow{4}{*}{ Missing } & DIT & 24 & 9.0 & 23.1 & 100.0 \\
Total & Total & 104 & 39.0 & 100.0 & \\
\hline
\end{tabular}

Table B9. Secondary name

\begin{tabular}{llllll}
\hline & & Frequency & Percent & Valid Percent & $\begin{array}{l}\text { Cumulative } \\
\text { Percent }\end{array}$ \\
\hline \multirow{4}{*}{ Valid } & ZANAKI & 31 & 11.6 & 30.1 & 30.1 \\
& JANGWANI & 31 & 11.6 & 30.1 & 60.2 \\
& MBEZI BEACH & 23 & 8.6 & 22.3 & 82.5 \\
& MAKONGO & 18 & 6.7 & 17.5 & 100.0 \\
\multirow{2}{*}{ Missing } & Total & 103 & 38.6 & 100.0 & \\
\hline
\end{tabular}




\begin{tabular}{lll}
\hline Total & 267 & 100.0
\end{tabular}

Source: Field data (2015)

Table B10. Reliability of the constructs

\begin{tabular}{|c|c|c|c|c|}
\hline Constructs & Items & Number of Items & $\begin{array}{l}\text { Cronbach's } \\
(>0.7)\end{array}$ & Apha \\
\hline \multirow{5}{*}{$\begin{array}{l}\text { Implementations of the } \\
\text { Best practices in } \\
\text { repayment in the pre } \\
\text { college preparations }\end{array}$} & $\begin{array}{l}\text {-Early education to the } \\
\text { existing models }\end{array}$ & \multirow[t]{5}{*}{5} & \multirow[t]{5}{*}{0.933} & \\
\hline & $\begin{array}{l}\text {-Presentation to promote } \\
\text { value of education }\end{array}$ & & & \\
\hline & $\begin{array}{l}\text {-National campaign to } \\
\text { promote education }\end{array}$ & & & \\
\hline & $\begin{array}{l}\text {-Organization of college } \\
\text { fair to educate on loan } \\
\text { repayment }\end{array}$ & & & \\
\hline & $\begin{array}{l}\text {-Employees' education at } \\
\text { work place }\end{array}$ & & & \\
\hline \multirow{5}{*}{$\begin{array}{l}\text { Implementations of the } \\
\text { Best practices in } \\
\text { repayment in the in } \\
\text { college period }\end{array}$} & $\begin{array}{l}\text {-Presence of students } \\
\text { financial aid offices }\end{array}$ & \multirow[t]{5}{*}{5} & \multirow[t]{5}{*}{0.880} & \\
\hline & $\begin{array}{l}\text {-Entry and exit } \\
\text { counselling sessions }\end{array}$ & & & \\
\hline & $\begin{array}{l}\text {-Reading carefully loan } \\
\text { provision contracts }\end{array}$ & & & \\
\hline & $\begin{array}{l}\text {-Presence of exit } \\
\text { interview to dropout }\end{array}$ & & & \\
\hline & $\begin{array}{l}\text {-Employment of default } \\
\text { specialists }\end{array}$ & & & \\
\hline \multirow{5}{*}{$\begin{array}{l}\text { Implementations of the } \\
\text { Best practices in } \\
\text { repayment in the after } \\
\text { college period }\end{array}$} & $\begin{array}{l}\text {-Beneficiaries reminded } \\
\text { to repay }\end{array}$ & \multirow[t]{5}{*}{5} & \multirow[t]{5}{*}{0.738} & \\
\hline & $\begin{array}{l}\text {-Maintenance of the } \\
\text { regular contacts with } \\
\text { borrowers }\end{array}$ & & & \\
\hline & $\begin{array}{l}\text {-Beneficiaries reminded } \\
\text { on the repayment date } \\
\text { and rate }\end{array}$ & & & \\
\hline & $\begin{array}{l}\text {-Establishment of } \\
\text { contacts with dropouts }\end{array}$ & & & \\
\hline & $\begin{array}{l}\text {-Setting of the repayment } \\
\text { date on the pay day }\end{array}$ & & & \\
\hline
\end{tabular}

Source: Field data (2015)

\section{Copyrights}

Copyright for this article is retained by the author(s), with first publication rights granted to the journal.

This is an open-access article distributed under the terms and conditions of the Creative Commons Attribution license (http://creativecommons.org/licenses/by/3.0/). 